\title{
Correction to: We'd rather pay than change: The politics of German non-adjustment in the Eurozone crisis
}

\author{
Nils Redeker ${ }^{1}$ (D) Stefanie Walter ${ }^{2}$ \\ Published online: 11 September 2020 \\ (C) Springer Science+Business Media, LLC, part of Springer Nature 2020
}

\section{Correction to: The Review of International Organizations (2020) 15:573-599 https://doi.org/10.1007/s11558-020-09390-1}

The title of the originally published version of this article, unfortunately, is incorrect. The correct title is "We'd rather pay than change: The politics of German nonadjustment in the Eurozone crisis".

\section{Nils Redeker}

redeker@delorscentre.eu

$\bowtie$ Stefanie Walter

stefanie.walter@uzh.ch

1 Jacques Delors Centre, Hertie School, Friedrichstraße 194, 10117 Berlin, Germany

2 University of Zurich, Affolternstrasse 56, 8050 Zurich, Switzerland 